\title{
Tysklands rolle i Europa
}

\section{Af Dr. Norbert Röttgen}

Mange af de store problemer, Europa står overfor, rækker ud over territorium og nationalstaters indflydelse, og der kan kun findes fyldestgørende svar på transnationale spørgsmål på den transnationale scene. Derfor er det nødvendigt at skabe et stærkt Europa.

Stefan Kornelius og jeg er blevet bedt om at behandle spørgsmålet om tysk genforening og udenrigspolitik i 2015. Man kunne være fristet til at behandle spørgsmålet i kronologisk orden - fra fortid til nutid, men jeg har valgt den omvendte orden og lægger ud med en kort vurdering af det aktuelle internationale landskab set fra et europæisk eller måske snarere et tysk-europæisk perspektiv. Derefter vil jeg se nærmere på Tysklands aktuelle rolle og de udfordringer som især Tyskland står overfor - og hvordan begge er forbundet med vores historie.

Først en hurtig karakteristik af den internationale situation, og her starter jeg med Rusland, der har sat spørgsmålstegn ved, udfordret - og krænket - vores fredelige europæiske orden. Den ukrainske krise er selvfølgelig ikke kun en bilateral konflikt mellem to lande, men en udfor- dring af vores fredelige orden - en orden som jeg troede var en almindeligt accepteret konsekvens og lektie af det 20. århundredes blodsudgydelser. Vi fik at vide og måtte tage til efterretning, at det forholdt sig anderledes, at vi måske levede i en illusion. Nu må vi forholde os til den kendsgerning, at denne orden er blevet krænket, og vi må håndtere situationen og arbejde på at etablere en ny form for fredsarkitektur. Det kommer vi til at beskæftige os med i nogen tid.

Dernæst er der Islamisk Stat, der må forventes at vare ved. Vi har en hel region, Mellemøsten/Nordafrika, der er karakteriseret af fejlslåede eller skrøbelige stater og udnyttet af en gruppe fanatiske terrorister, som hævder at ville etablere en stat i en region, hvor vi normalt har set, at staters autoritet har slået fejl. Og ophavet til konflikt i regionen - den israelsk-palæstinensiske konflikt - er havnet $i$ et dødvande.

Endelig har vi den aktuelle flygtningekrise - selv om den ikke kan måle sig med IS og den trussel, den medfører for regionen og for os. Vi ved alle, at det tomrum, som fejlslagne stater efterlader, fyldes med kriminelle grupper, der bedriver menneskehandel; men den under-

Dr. Norbert Röttgen er formand for udenrigsudvalget i Den Tyske Forbundsdag. (Tale i Festsalen, Københavns Universitet, den 2. september 2015. Den publiceres med støtte fra Europa-Nævnet]. 
liggende kendsgerning er sammenstødet mellem menneskers helt forskellige levevilkår. Det er sammenstødet mellem en region fyldt med desperation - elendighed, død og vilkårligt styre - og en region, et kontinent, fyldt med håb. De regioner er kun adskilt af Middelhavet, og mens vi på den ene side holder ferie, ser vi på den anden dagligt død, uretfærdighed, terror og rystende situationer. Mobiltelefoner slår i dag bro over dette hav. Alle kan kommunikere, og alle ved, at der findes håb på den anden side. Mennesker desperate nok til at risikere deres liv for at komme over på den anden side - det er den grundlæggende situation vi står overfor.

\section{Europas krise}

Vi står over for disse udfordringer, disse forhold med rystede eller bristede or- dener omkring os. Vi, europæerne, udfordres af disse forhold. Hvad med os - Europa? Som jeg ser det, står Europa over for sin dybeste og mest alvorlige krise siden Rom-traktaten - siden den europæiske integrationsproces blev sat i gang.

Vi er alle steder vidne til en solidaritetskrise, og solidaritet er det princip, Europa er bygget på. Der er dukket en ny nationalisme op, en ny populisme, med indadskuende, selvcentrerede holdninger.

Overalt - i alle lande - søger enhver, der er involveret i politik, opbakning på hjemmebanen, men ved at søge den hjemmebanen lammer vi vores evne til som europæere at handle sammen. Kløfterne er så dybe som aldrig før.

EU har ændret sig, siden finanskrisen i 2008 rystede euroen i sin grundvold.

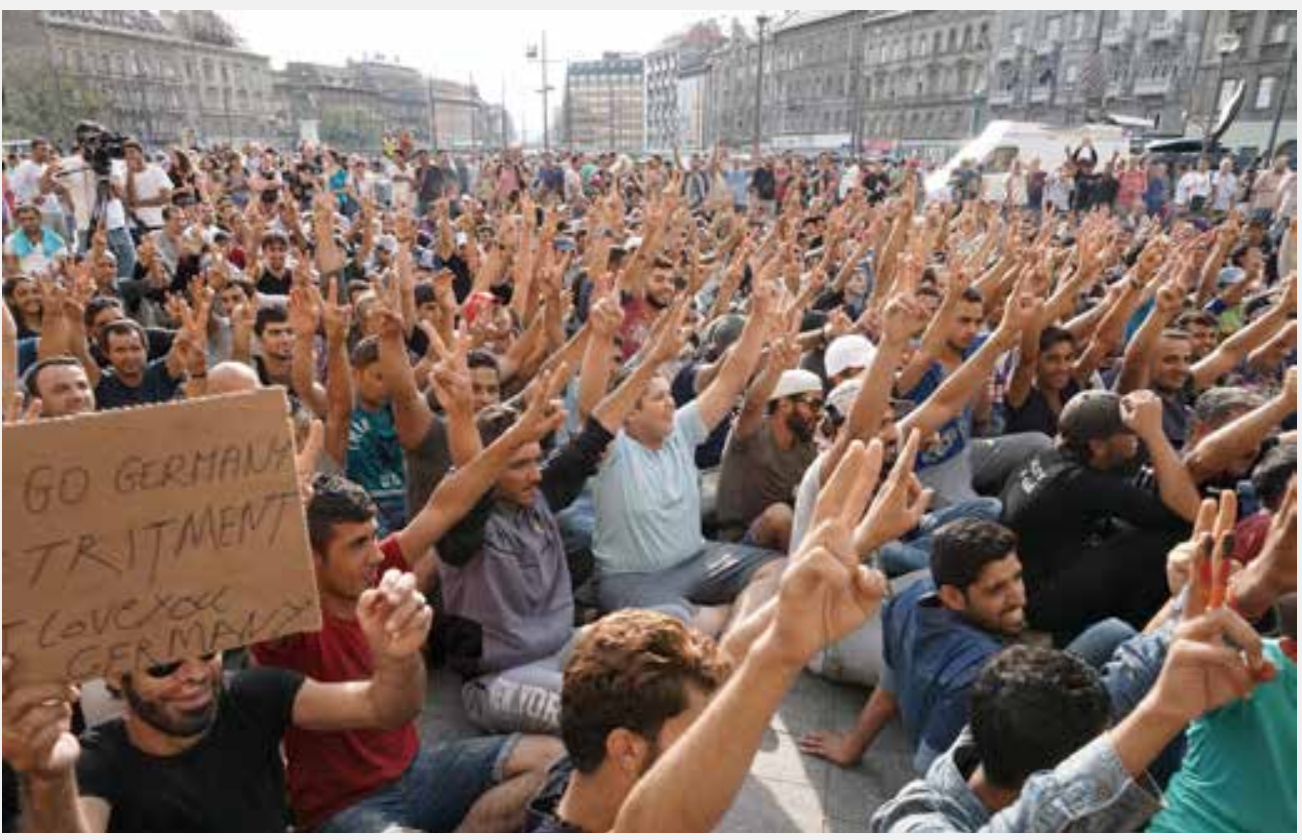

FOTO: Mstyslav Chernov via Wikimedia Commons

Syriske flygtninge foran banegården i Budapest, september 2015 
EU har ændret sig, siden finanskrisen i 2008 rystede euroen i sin grundvold. $\mathrm{Nu}$ er vi forskellige. Nu er vi ikke længere ligemænd. Nu har vi vindere og tabere - långivere og låntagere. Vi definerer os selv som havende forskellige nationale interesser - og dermed lammer vi Europa.

$\mathrm{Nu}$ er vi forskellige. Nu er vi ikke længere ligemænd. Nu har vi vindere og tabere - långivere og låntagere. Vi definerer os selv som havende forskellige nationale interesser - og dermed lammer vi Europa. For at opsummere så er Europa både så udfordret og så uforberedt som aldrig før. Men ikke desto mindre er det i kraft af Europa - i den aktuelle udformning og med de aktuelle udfordringer at en hvilken som helst europæisk stat kan få indflydelse. Ingen europæisk nationalstat er på egen hånd i stand til at udøve nogen som helst relevant indflydelse på den globale scene, til virkelig effektivt at tage fat på og forme nogen af de internationale trusler og udfordringer, som vi står overfor.

Derfor mener jeg, at det står fast, at Europa har afgørende betydning!

\section{Tyskland og Europa}

Og så kommer jeg til dagens emne. Det synes at være en ny kendsgerning, at Tyskland er vigtigere for Europa end nogensinde tidligere. At spille en afgørende rolle er ikke noget Tyskland selv har stræbt efter. Vi har ikke haft nogen ambition om at dominere eller forme Europa. Vi har ikke søgt en ledende rolle.

Men det er en kendsgerning, at størrelsen og Tysklands økonomiske og politiske stabilitet pålægger os et særligt ansvar: Ansvaret for at skabe europæisk enhed og skabe et Europa, der er i stand til at optræde som en samlet, troværdig aktør i international politik. Jeg vil beskrive Tysklands rolle som at bidrage til at styrke Europas evne på det udenrigsog sikkerhedspolitiske område med hen- blik på at sætte Europa i stand til, i et vist omfang, at medvirke til at løse internationale kriser, der påvirker Europa som helhed.

Som nævnt er det ikke noget vi har stræbt efter, men vi må acceptere situationen. Kriserne bliver stadigt hyppigere, de kommer tættere på, og de bliver mere og mere indbyrdes forbundet. Og de er alle europæiske kriser: Ukraine og vores europæiske fredelige orden, flygtningekrisen og oprøret i Mellemøsten, vores nabo mod syd. Det er europæiske kriser, som kun har europæiske løsninger.

Vi må derfor udvikle Europa til en fyldestgørende aktør på dette område, en aktør, der kan tilvejebringe fyldestgørende svar og reaktioner på disse forhold. Er vi forberedt på det? Absolut ikke. Her kommer vores historie ind i billedet. Vores efterkrigshistorie lærte os ikke at påtage os en sådan rolle, og vi gjorde det ikke.

Hvis man for halvandet eller to år siden havde spurgt tyskerne, hvordan de ønskede at deres udenrigspolitik og internationale rolle skulle være, om de ønskede at være et stort Schweiz, vil jeg hævde, at et stort flertal ville have svaret, at det ville være en fortræffelig, komfortabel rolle for Tyskland. Som et stort Schweiz kunne Tyskland nyde sin økonomiske succes uden at blive inddraget $i$ alle mulige hæslige konflikter og krige. Vi ville holde os på afstand af disse krige, fordi vi ved, at det økonomisk og politisk er dyrt og risikabelt at blive inddraget, men jeg tror vi efterhånden har lært, at det ikkelængere er muligt.

Efter Anden Verdenskrig var vi ikke $i$ en position til at bede om nogen som 
helst udenrigspolitisk rolle. Vores ambition var i årtier at blive genintegreret, at genvinde tillid. Vi var en frontlinje-stat i sammenstødene under den kolde krig, og efter 1990 synes historien at have udviklet sig i en for os overraskende venlig retning: Vi genforenede fredeligt vores land, og vi følte os omgivet af venner.

"Har vi overhovedet brug for Bundeswehr, har vi brug for et forsvar". Som alle andre tog vi fredsdividenden for givet, vi oplevede gode tider, og regnede med, at de ville vare ved. Og vi gjorde en ny erfaring - at Tyskland tæller, at Tyskland betyder noget. Jeg vil vove at påstå, at vi i Tyskland har udviklet en udenrigspolitisk konsensus blandt dem, der professionelt beskæftiger sig med udenrigspolitik. I Forbundsdagen er der mere eller mindre 90 procents enighed om udenrigspolitikken, kun Venstrepartiet står uden for denne enighed. De Grønne, der startede fredsbevægelsen, er en del af den udenrigspolitiske konsensus.

\section{Tysklands ansvar}

Det betyder, at vi må påtage os ansvaret, ikke kun inden for egne grænser, men også, som en europæisk magt, uden for vores grænser. Deler befolkningen det synspunkt?

Jeg tror vi bliver nødt til at give befolkningen tid. Vi er ikke vant til en sådan situation, den er ny for os. Vi har ikke bedt om den, og vi har brug for tid til at blive fortrolig med den. Men jeg tror virkeligheden er den bedste læremester. Virkeligheden tvinger os til at tilpasse os, og vi vil tilpasse os. Det kræver lederskab at forklare, at det ikke handler om at militarisere vores udenrigspolitik, at det ikke handler om at udbrede tysk dominans eller hegemoniske ambitioner, men om at påtage sig det ansvar, der følger af Tysk- lands størrelse og økonomiske stabilitet. Jeg læste i Financial Times, at arbejdsløsheden i Tyskland er under seks pct. I Italien er ungdomsarbejdsløsheden 42 pct., i Frankrig i den 24-25 pct., så den $ø$ konomiske situation i nogle af de store lande i Europa er dyster.

Har vi indtil videre levet op til udfordringerne?

I forhold til krisen i Ukraine vil jeg sige 'ja'! Kansleren er konfronteret med krisen for Europas fred, og hun har været mere åbenhjertig end normalt. Hun har været fuldstændig klar i mælet, og hun kommunikerer sin politik til den tyske offentlighed. Hun har med held arbejdet for at skabe europæisk enighed. På trods af forskellige og modsatte interesser mellem ikke kun små europæiske medlemslande er det indtil videre lykkedes, således at Ukraine ikke er kollapset, at Ukraine har faet lov til at bestemme sin egen skæbne - bestemme hvilket normativt værdisystem det ønsker at tilhøre. Jeg taler ikke om institutioner, men om normative værdisystemer. De ønsker at tilhøre Vesten og vestlige værdier, og de har ret til at bestemme deres egen skæbne. Vi står solidarisk med denne ret som europæere.

Hvad angår Grækenland og euroen vil jeg sige, at vi - efter en vis irritation sørgede for, at den europæiske og tyske solidaritet fortsatte og dermed undgik, at euroen brød sammen.

I midten af august vedtog vi i parlamentet igen at støtte Grækenland med en enorm sum penge. Hvis vi ikke havde gjort det, ville vi ikke blot have føjet yderligere usikkerhed til en i forvejen relativt skrøbelig økonomisk situation, men vi ville også have mister legitimiteten og autoriteten til at forme europæisk solidaritet i andre tilfælde, hvor der er behov for solidaritet. 
Det er nødvendigt med solidaritet $\mathrm{i}$ forhold til konflikten med Rusland på grund af Ukraine. Og det er nødvendigt i forhold til flygtningekrisen - den tredje krise, som vi står overfor, og en krise, som jeg beskrev som resultat af sammenstødet mellem vidt forskellige eksistensvilkår: På den ene side forventninger om rigdom, fremgang og lykke og på den anden en hel regions fortvivlelse.

\section{En europæisk løsning}

Det er en europæisk udfordring, og indtil vi finder en europæisk løsning, har vi ikke et fyldestgørende svar. Vi må leve op til den mentalitet, som ser engagement i udenrigs- og sikkerhedspolitik som et permanent element $i$ en politisk tilgang til at skabe fremtiden og til at udfolde og forfølge vores værdier og interesser. Det koster. Det vil have finansielle omkostninger på kort sigt, men det vil tjene sig ind på lang sigt. Vi må overbevise folk om nødvendigheden af at engagere sig nu, af at øge de finansielle og politiske omkostninger, men se det som en investering $i$ at opbygge og etablere i det mindste elementer af politisk orden på den transnationale og internationale scene.

De store problemer rækker ud over territorium og nationalstaters indflydelse, og vi kan kun finde fyldestgørende svar på transnationale spørgsmål på den transnationale scene. Hvis vi skal blive i stand til at håndtere disse udfordringer, er det nødvendigt at skabe et stærkt Europa - og et stærkt Europa kan ikke skabes uden Tyskland. Dét er vores ansvar, men det er også vores fremtid og vores interesse. $\mathrm{Og}$ i sidste ende er det fine, at selv om europæiske interesser og perspektiver og nationale interesser og perspektiver på kort sigt kan synes forskellige, så falder de sammen og bliver identiske på lang sigt. Behovet, ansvaret, opgavens vigtighed skal diskuteres offentligt, ikke kun i professionelle kredse bag lukkede døre.

Derfor var jeg glad og beæret over at blive bedt om at præsentere nogle af mine tanker for dette publikum. Tak!

(Oversat fra engelsk af Brita V. Andersen) 